\title{
An Analysis of The Application of IQ-Analytical Writing Guide on ESL Students' Essay Writing Performance and Interest
}

Noriah Ismail, Haryati Ahmad, Suhaidi Elias@Alias, Noor Sufiawati Khairani, Herlina Wati, Suciyati Sulaiman

To Link this Article: http://dx.doi.org/10.6007/IJARBSS/v11-i3/8334

DOI:10.6007/IJARBSS/v11-i3/8334

Received: 10 January 2021, Revised: 13 February 2021, Accepted: 28 February 2021

Published Online: 14 March 2021

In-Text Citation: (Ismail et al., 2021)

To Cite this Article: Ismail, N., Ahmad, H., Elias@Alias, S., Khairani, N. S., Wati, H., \& Sulaiman, S. (2021). An Analysis of The Application of IQ-Analytical Writing Guide on ESL Students' Essay Writing Performance and Interest. International Journal of Academic Research in Business and Social Sciences, 11(3), 394-405.

\section{Copyright: @ 2021 The Author(s)}

Published by Human Resource Management Academic Research Society (www.hrmars.com)

This article is published under the Creative Commons Attribution (CC BY 4.0) license. Anyone may reproduce, distribute, translate and create derivative works of this article (for both commercial and non-commercial purposes), subject to full attribution to the original publication and authors. The full terms of this license may be seen at: http://creativecommons.org/licences/by/4.0/legalcode

Vol. 11, No. 3, 2021, Pg. 394 - 405

Full Terms \& Conditions of access and use can be found at http://hrmars.com/index.php/pages/detail/publication-ethics 


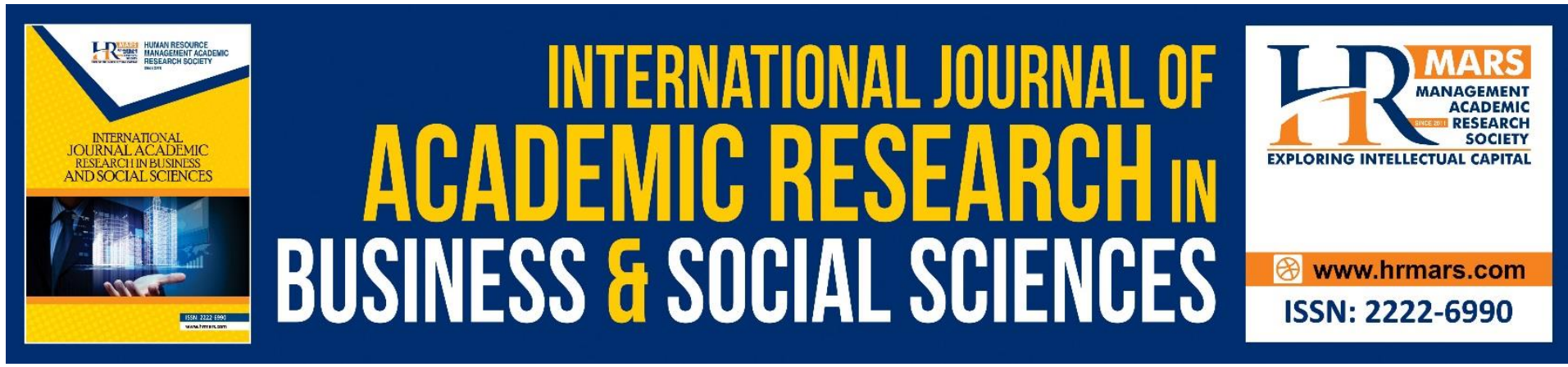

\title{
An Analysis of The Application of IQ-Analytical Writing Guide on ESL Students' Essay Writing Performance and Interest
}

\author{
Noriah Ismail, Haryati Ahmad, Suhaidi Elias@Alias, Noor \\ Sufiawati Khairani, Herlina Wati, Suciyati Sulaiman \\ ${ }^{1}$ Universiti Teknologi MARA Cawangan Johor (MALAYSIA), ${ }^{2}$ Universitas Lanchang Kuning \\ (INDONESIA), ${ }^{3}$ Universiti Brunei Darussalam (BRUNEI DARUSSALAM)
}

\begin{abstract}
The study investigates the use of IQ-Analytical Writing Guide (IQ-AWG) for writing task developed for ESL tertiary students at MARA University of Technology Malaysia (UiTM). The participants in this study were 60 Part Three Diploma students from UiTM taking an English proficiency course known as ELC231 (Integrated Language Skills III: Writing) from two different randomly selected classes. The experimental group, consisted of 30 students used IQ-AWG for essay writing; whereas, the other 30 students in the control group learned essay writing without it. Two experienced ESL writing instructors were selected to evaluate all participants' essay marks against CEFR. The students in the experimental group were given Post-instruction Questionnaire. The data were analyzed using the quantitative and qualitative measures. The T-Test was used to support the data analysis. The results indicated a better writing performance from the experimental group with the use of IQ-AWG. Moreover, the data obtained from the questionnaire revealed the students' perceived the use of IQ-AWG help them reduce their writing anxiety as well as increase their interest to write.
\end{abstract}

Keywords: ESL, Academic Writing, Analytical Writing, Writing Performance, Writing Apprehension, Writing interest, Critical Thinking

\section{Background of The Study}

Writing in English is one of Malaysian ESL learners' greatest weaknesses. They tend to have writers block due to lack of ideas. Moreover, many students seem to lack critical thinking when writing that their content is often dull and uninteresting (Ramachandran, 2004; Ismail, Hussin \& Aboswider, 2019).

Traditionally, many ESL teachers tend to generalize that ESL students only needed to be drilled with a lot of grammar exercises or getting their written products error free (Raimes, 1991). Their primary focus was on the surface structure. This over concern on the form resulted in the lack of attention given to the strategies on how to write better or on the use of the right techniques and activities that can facilitate better writing so that the students are able to produce essays which are profound and interesting to read (Rankin-Brown, 2006; Maznun et al., 2017). Due to this, many ESL students were not able to produce a good piece 
of work and only obtain a poor grade despite being able to turn in an error free essay (Warschauer \& Healey, 1998; Ismail, 2010; Ismail \& Albakri, 2012).

Therefore, it is important that ESL students are exposed to better writing activities such as through the use of a good composing guide which is designed to enhance the learner critical thinking skills through learner inquiry and not just spoon feed them with the answers or given points such as through the directed writing tasks which are no longer suitable for tertiary students (Mah \& Er, 2009; Ismail, 2010; Hussin, Abdullah, Ismail \& Soo, 2015). This emphasis on critical thinking and learner inquiry are also in line with the Constructivist Learning Theory. Constructivist learning strategies capitalize on learning through inquiry and problem solving via critical and creative thinking (Brown et al., 2002). Moreover, according to Exline (2004), student inquirers are encouraged to explore new ideas and understandings through personal discoveries and explorations as well as interactions with objects and with other people. Writing is enhanced through the inquirers' opportunity to engage in real life activities, situations and with real audience.

ESL students need to be taught more on how to develop their ideas and critical thinking especially in writing. Otherwise, they can only produce an accurate but dull or even irrelevant piece of work (Ismail, Hussin \& Darus, 2012; Ismail, Elias, Muthusamy, \& Perumal, 2014b). For instance, many ESL tertiary students were not able to think critically or deeply when describing a particular issue in their writing, even when such problems have been noted by the lecturer in their revised drafts (Ismail, Maulan \& Hassan, 2008). This lack of critical thinking skill has resulted in the lack of in-depth content and dull essay presentation by many ESL tertiary students. Such a problem does not only occur among ESL tertiary students from MARA University of Technology but also has been reported in other institutions as well such as among Universiti Malaysia Serawak (UMS) students (Osman \& Abu Bakar, 2009). Therefore, students need to be allowed to be inquisitive when writing and given ample time to practice writing even outside class time such as by using an effective writing guide and resources which is designed to cater to their lacks and needs.

In addition, another factor that needs to be emphasized on is students' interest and motivation towards learning which will help to enhance their learning performance (Ismail, Ratan Singh, Elias \& Albakri, 2015; Motevalli et al., 2020). Reid (1993) contends that one of the most prominent factors affecting students' success in college composition is their interest and attitude towards their writing task. Therefore, how the students feel and react towards their writing tasks greatly determines the quality of their composition.

To that end, IQ Analytical Writing Module, the feature of this study, is a supplementary writing guide that uses inquiry-based learning techniques and composing guide which emphasizes analytical and critical thinking as well as Autonomous Learning Model (Betts \& Kercher, 1999) and related ESL communicative learning theories (Krashen 1985; Kroonenberg, 1995; Kuhn \& Chuo, 2002) as its basis. Moreover, IQ Analytical Writing module is also based on the needs analysis for supplementary writing module conducted in the previous study by Noriah et al (2015). In this study, its role will be extended to reducing writing apprehension and enhancing writing skill among students. The study will be conducted among a group of 60 ESL Tertiary Level students at UiTM Cawangan Johor studying ELC231 English for Academic Writing.

\section{ESL Tertiary Students' Need for a Special Composing Guide}

From a needs analysis study conducted on ESL tertiary students at MARA University of Technology, it was discovered that the students face weaknesses in terms of the language use but most significantly, they were not critical during their writing process which leads to 
carelessness when writing as well due to their inability to produce in-depth and interesting essays (Ismail, et al., 2016; Maznun et al., 2017). In addition, they need more time to practice writing online and autonomously in order to enhance their writing ability (Mah \& Er , 2009).

Furthermore, many ESL tertiary students face problems in learning to write which occur mostly due to ineffective writing modules or activities (Ismail, et al. 2016) lack of writing practice in class ( Adzmi, 2009) proper guidance and scaffolding as well learner discussions. Therefore, in order to enhance ESL students' writing ability as well as interest towards writing many researchers regarding ESL writing suggest that the students be given suitable online composing guide and scaffolding (Hussin, 2008) in order to write successfully.

\section{IQ-Analytical Writing Guide for ESL Students}

IQ-Analytical Writing Guide is the main feature of IQ-Analytical Writing Module. It is a modified version of the earlier composing guide in IQ-Write Program which was a supplementary online learning program for BEL311 students (The earlier version of ELC231). IQ-Analytical Writing Guide was developed based on the findings from ESL writing need analysis study conducted on UiTM Diploma Part Three students' which found that the students were not able to produce good quality essays due to the fact that they were not critical during their writing process (Ismail, et al. 2010; Ismail et al., 2014a). In addition, the students also need a lot of writing practice (Ismail et al., 2012b) both in and out of class time so it would be beneficial to have a composing guide which can be accessed online together with other online learning tools such as e-forum and some suitable online links and resources pertaining to their writing needs (Hussin, 2008; Mah \& Er, 2009; Ismail \& Albakri, 2013). Insofar, IQ-AWG was developed based on these needs as well as the learning theories and method namely; the Constructivist Learning Theory which stresses on learner social interactions, the Affective Filter Theory by Krashen (1985) which focuses on learner interest as well as the Inquiry - Based Learning method which emphasizes on learner inquiry and autonomy especially via technology or online learning method (Exline, 2004).

\section{The Features of IQ-AWG}

IQ-AWG consists of 7 writing steps which the students need to follow (in a recursive manner as it employs the process writing approach) which include:

1. ASK - At this stage students will inquire about their aims for writing the essay or assigned paper and how they are going to achieve them.

2. FOCUS - During this stage students need to answer some important questions pertaining to their topic and scope.

3. SEEK - This is the phase where the students seek information regarding their topic and have to think about choosing the right materials and resources.

4. PRODUCE - When producing or writing out their draft students are encouraged to be critical and think about producing relevant and interesting contents or ideas for their essays.

5. CORRECT -At this stage students have to proofread and revise their work and to help them do this carefully they have to answer some important questions and checklists.

6. EVALUATE - At this stage students are to evaluate one another's work and they are given a set of questions and checklist to help them go through with this step.

7. REFLECT \& REEVALUATE - Once the students have completed their essays they are encouraged to reflect on and reevaluate their writing process through self-inquiry in order to ascertain their own writing strengths and weaknesses for improvement. 
To help the students during each of these writing steps, IQ-AWG provides some very useful Guide Sheets and Tip Sheets which consist of important guides and tips as well as some interesting writing tasks and exercises related to each step. It is important to note that the Guide and Tip Sheets are not used to spoon feed the students with the information regarding writing, instead they are meant to get them to think for themselves regarding their writing process and to be very inquisitive and critical when writing. That is why the guides and tips are provided in terms of inquisitive and explorative questions and not in directives. To use IQAWG the students need to access it online via u-Future which was the online learning MOOC for the university after they have registered to be the participants of this program. Moreover, the students could also discuss their use of IQ-AWG using the special forum provided in the program known as i-Discuss. In this way the students were able to interact and provide each other with feedbacks and evaluate one another's written tasks and exercises.

\section{Significance of the Study}

Many previous researches claim that students' interest towards learning essay writing may enhance students' writing skills and performance (Sullivan, 2006; Osman \& Abu Bakar, 2009). Therefore, it is important to discover the general level of writing apprehension as well as identify ESL students' perception on the best way or technique for them to learn to write academic essays especially those at the tertiary level. Few previous researches have focused specifically on writing apprehension (Maznun et al., 2017) particularly on expository essay writing as well as on the use of analytical writing technique for ESL tertiary students. Thus, the findings of this study would contribute to this particular field of knowledge.

\section{Purpose of the Study and Hypothesis}

This study was designed for two major purposes. First, it was designed to address the direct effect of the use of IQ-AWG on the students' writing performance. For this purpose, hypothesis 1 was generated:

Hypothesis 1: The IQ-AWM will improve students' writing performance.

Second, the study was designed to investigate whether the students have a favorable perception of the use of IQ-AW Module for writing instruction.

\section{Methodology}

\section{The Participants}

The participants of this study consist of sixty Part Three Diploma students who were taking a compulsory English proficiency course at The Universiti Teknologi MARA Cawangan Johor Malaysia. The course is known as The Integrated English Language Course and was held as two-hour face to face in class instruction and another two as a blended learning or online instruction. The course focuses mainly on the writing skill even though the other three language skills which are reading, listening and speaking are also taught. The students from the two randomly selected classes (thirty students in each class) were assigned, one as the control group and the other as the experimental group.

\section{The Instructor}

The instructor, a senior lecturer, has been teaching English as a second language for over fifteen years in the Academy of Language Studies at the university. She obtained a master's degree and a PHD in English Language Studies. However, she had not utilized the IQ-AWG for teaching writing prior to this research project. Her role in this research was providing 
traditional writing instruction to participants in the control group and IQ-AWM Instruction to participants in the experimental group.

\section{The Instruments}

The instruments used in this study were IQ-Analytical Writing Module particularly the IQAWG, Writing Performance Test and the Post-instruction Questionnaire. The Writing Performance test consisted of a pretest and a posttest in which participants were asked to perform a writing task (expository essay). Two experienced ESL writing instructors were selected to evaluate all participants' writing tests against CEFR. The average reliability coefficient for two readers (evaluators) was reported to be 0.91 (Jacobs et al., 1981). The Post-instruction Perception Questionnaire developed for this study was distributed to the students in the experimental group. It was used to obtain the students' perception of the use of IQ-AWG and resources as experienced in the IQ-AWM Instruction program. The first part of the questionnaire consists of 10 statements. In a 4-point Likert scale format, participants were asked to agree or disagree with the statements. The second part of the questionnaire contains open-ended questions inquiring further about participants' perception and comments regarding the IQ-AWM classroom instruction.

\section{Variables and Data Analysis}

The major variables included writing instruction, student writing performance and student perception. The Statistical Package for the Social Sciences software (SPSS) was used for data analysis. Data collected were analyzed via t-test and descriptive analysis.

\section{Research Procedures}

At the beginning of the research project, the Writing Performance Pretest was administered to the participants in the experimental group as well as the control group. Both groups received ELC231 writing instructions two hours a week from the same instructor. The participants from both groups were asked to complete a writing task that consists of two expository essays which focus on the same topics. Most importantly, the control group was given the traditional writing instruction from the prescribed textbook whereas the experimental group was required to write their writing tasks with the help of IQ-AWG. At the end of the research project, the Writing Performance Post-test was administered to the participants in both groups. The Post-Instruction Questionnaire was administered to the experimental group who received the IQ-AW Guide. This research project was conducted over 8-week period.

\section{Results and Discussion}

\section{Effect of Instruction Method on Writing Performance (Overall Score)}

The marks obtained by the two groups for the overall score were used to obtain the following results:

Table 1: Mean and Standard Deviation for Overall Score

\section{Overall Score}

\begin{tabular}{lll} 
& Experimental Group & Control Group \\
\hline Mean & 76.72 & 60.92 \\
S.D & 7.24 & 7.26 \\
\hline
\end{tabular}


A t-test was used to analyze the difference between the writing performance pre- and posttest scores in the control group (traditional writing instruction) and the experimental group (IQ-AWG instruction).

Table 2: T-test for Overall Score

\begin{tabular}{lccc}
\hline Variable & t-value & df & 2-tail sig. \\
\hline Overall Score & 8.55 & 59 & 0.00 \\
\hline
\end{tabular}

Table 4.2 shows that the experimental group had performed significantly better compared to the control group. The result obtained implies that the use of IQ-AWG enabled the students in the experimental group to produce better essays when compared to the students in the control group. Hence Hypothesis 1 is accepted.

\section{The Students' Perception of the Use of IQ-AWG for Essay Writing Instruction}

Below are some of the excerpts from the experimental students regarding IQ-AWM instruction particularly the use of IQ-AWG which clearly show the students' favorable perception towards its use in learning to write academic writing:

IQ-AW guide is very effective to use when learning writing because it has the Guide Sheets and Tip Sheets helps me to be more analytical when writing my essays. (Student $10 / \mathrm{S} 10$ )

Well, I think I like the IQ-AW guide because it got me to be critical when I edit my writing. Usually I just tend to submit my essay without editing it carefully but with the help of this guide I am more careful (Student 23) This IQ-Analytical Writing Guide really helps me to write better because it shows me the step by step process and guide me to be inquisitive when proofreading so that I become very careful when writing and also am well-guided in every step - from first till the end. It also helps me to reflect and evaluate my essays. (Student 13)

IQ-AWG is most useful when writing my research paper because of the many resources and the checklist items are useful for reminders. I can use the items in the Guide Sheets and Tip Sheets to ask myself the important questions throughout my writing process and to revise my writing. It also helps me to write in a critical and interesting way so that I no longer produce irrelevant content in my essays. (Student 14)

With these useful guides for writing I feel less apprehensive when instructed to write essays (Student 17)

We can speculate as to why the use of IQ-AWG was more effective than the traditional writing activities. Firstly, the students who use IQ-AWG feel that it has helped them to write in a critical manner as they were able to be inquisitive and critical throughout their writing process which stimulates their thinking process, instead of being spoon-feed with the information which inhibits them to think critically like they experienced in the traditional class. This is in line with researches on second language writing which suggests that learners may improve their writing ability if they are encouraged to be self-exploratory and given the freedom to be critical and self-expressive (Alias \& Hussin, 2002; Exline, 2004). Thus, students who use IQ-AWG in the program outperformed their counterparts in the traditional writing instruction probably because the former spent a substantial amount of time thinking, revising, 
discussing and reflecting and as a result they were able to communicate better ideas in their writing (Lin \& Hsu, 2000; Exline, 2004; Tan, Emerson \& White, 2006; Osman \& Abu Bakar, 2009; Yuen \& Mussa, 2015).

Secondly, another fundamental distinction between these two was the way the writing instruction and input was provided. While the traditional method relies solely on textbook, handouts as well as oral discussions held in class, the students who participated in IQ-AW Program uses IQ-AWG which also helped them to utilize the writing guide and resources in this writing module made available to them in the University online learning platform or MOOC known as U-Future. Therefore, not only do they find IQ-AWG to be useful in helping them to write critically, but they also find the technique itself to be more interesting and challenging thus helping them to reduce their writing apprehension. This finding supports Krashen (1985) Affective Filter Theory of the need to use meaningful and interesting teaching techniques and activities as language learners learn best through such instructions. Moreover, many scholars also support writing instructions via online which they believe are more flexible and suitable with the needs of present tertiary students who value and benefit more from autonomy and online collaboration in learning (Felix, 2001; Supyan Hussin, 2008).

\section{Conclusion}

The significant findings in the writing performance and favorable perception of the use of IQAWG in ESL Writing class in this study are in line with previous studies on the use of ESL/EFL language learning instruction in which effective writing tools, guides and resources were utilized (Alias \& Hussin, 2002; Exline, 2004; Huwari \& Hashima, 2011; Yuen \& Mussa, 2015). It also strengthened the results of prior studies on the importance of being self-explorative, inquisitive and to be critical when writing in order to enhance one's writing performance (Osman \& Abu Bakar, 2009; Ismail et al., 2016) and thus, such learning opportunity and initiatives should be provided to all ESL tertiary students.

Thus, from the findings of this research, it is hoped that, curriculum development and administrators, ESL course book developers as well as writing instructors are more aware of the current problems faced by the students regarding academic writing especially regarding writing problems and needs. Insofar, they would then strive to find viable ways to tackle the problems such as through the implementation of interesting and effective writing techniques and modules. In addition, many previous researches regarding tertiary students' writing interest and performance have been conducted on writing in general (Alias \& Hussin, 2002; Maznun, et al., 2017) however, few have focused specifically on expository essay writing as well as on the use of analytical writing technique for ESL tertiary students. Thus, the findings of this study would contribute to this particular field of knowledge.

\section{References}

Adzmi, N. A. (2009). The academic English language needs of industrial design students in UiTM Kedah, Malaysia. English Language Teaching, 2 (4),717-718.

Alias, N., \& Hussin, S. (2002). E-learning in a writing course at Tenaga National University. TEFL Web Journal, 1 (3). Retrieved May 23, 2003, from http://www.teflwebj.org/v1n3/Alias_Hussin.htm

Brown, N. T., Mc Cormack, M., \& Zimmerman, R. (2009). An analysis of the research and impact in education in developing country contexts. Journal of Education for International Development, 4(2), 1-9. 
Choo, N. K. (2001). The case of comprehensible input in teaching and learning the write stuff. Proceedings of the FIFTH MELTA Biennial International Conference (pp.11-21). Petaling Jaya, Malaysia.

Exline, J. (2004). Concept to Classroom: Inquiry-Based Learning. Retrieved February 12, 2010. from http://www.thirteen.org/edonline/concept2class/inquiry/credit

Felix, U. (2001). A multivariate analysis of students' experience of web-based learning. Proceedings of the ASCILITE Conference. Retrieved January 20, 2003, from http://www.ascilite.org.au/ajet/ajet17/felix.html

Husin, S. (2008). Creating a bigger Z.P.D. for ESL learners via online forum. The College Teaching Methods and Styles Journal, 4 (11), 1-9.

Huwari, I., \& Hashima, N. (2011). Writing apprehension in English among Jordanian postgraduate students at Universiti Utara Malaysia, Academic Research International, 1(2),190-198.

Ismail, N., Hussin, S., \& Aboswider, R. O. S. (2019). Examining the Mechanism Utilized by CML Web-Logging Instructors in ESL Classrooms: A Case Study. The Asian Journal of English Language and Pedagogy. 7 (2), 31-39.

Ismail, N., Hussin, S., \& Darus, S. (2016). Investigating the Impacts of IQ-Write Online Writing Program toward ESL Students' Attitude and Interest in Learning Academic Writing. The International Journal of The Interdisciplinary Educational Studies, 11(1), 21-34.

Ismail, N., Singh, R. D. S., Elias, S., \& Albakri, M. A. I. S. (2015). A needs analysis study for SMART Online Academic Writing Module. Proceedings of the $8^{\text {th }}$ International Conference of Education, Research and Innovation (ICERI). (pp. 7062-7065). Madrid, Spain: IATED.

Ismail, N., Albakri, M. A. I. S., Wan Mustapha, W. Z. (2014a). ESL students' blended learning experience: A case study in an intermediate ESL writing class at Universiti Teknologi MARA. Proceeding of the 8th International Technology, Education \& Development. (pp. 3013-301). Spain: IATED.

Ismail, N., Albakri, M. A. I. S. (2013). The use of students' personal self-reflective blog for academic writing activities among ESL tertiary level students. Proceeding of the 5th International Conference on Education and New Learning Technologies EDULEARN13. (pp. 4617-4621). Barcelona Spain: IATED.

Ismail, N., Singh, R. D. S., Abu, R. (2013). Fostering learner autonomy and academic writing interest via the use of structured e-Forum activities among ESL students. Proceeding of the 5th International Conference on Education and New Learning Technologies Edulearn13. (pp. 4622-4626). Barcelona Spain: IATED.

Ismail, N., \& Albakri, M. A. I. S. (2012). An Analysis of ESL Students' Attitude and Interest Towards Learning to Write Essays using Selected Online Writing Links and Resources. The International Journal of Knowledge, Culture and Change Management, 11(6), 187198.

Ismail, N., Hussin, S., \& Darus, S. (2012a). ESL Students' Attitude, Learning Problems and Needs for Online Writing, GEMA Online Journal of Language Studies. 12 (4),10891107.

Ismail, N., Darus, S., \& Hussin, S. (2012b). ESL Tertiary Students' Writing Needs: A Framework for a Supplementary Online Writing Program, Asean Journal of Teaching and Learning in Higher, 4(2), 61-78.

Ismail, N., Maulan, S., \& Hassan, N. (2008). The impact of teacher feedback on ESL students' writing performance. Jurnal Akademik UiTM Johor, 8(1), 45-54. 
Krashen, S. D. (1985). The input hypothesis: Issues and Implications. New York: Longman.

Mah, B. Y., \& Er, A. N. (2009). Measuring students' perception of writing web logs in ESL classroom employing the Technology Acceptance Model. Conference on scientific and Social research, (pp.1-9). Malaysia.

Mak, L., \& Mak, S. (1995). What's out there? Summarizing information from the web. In M. Warschauer (Ed.), Virtual Connections (pp. 328-329). Honolulu, Hawaii: Second Language Teaching \& Curriculum Center, University of Hawaii.

Maznun, M. D., Monsefi, R., \& Nimehchisalem, V. (2017). ESL undergraduates' difficulties in writing: The introduction for research reports. Advances in Language and Literary Studies, 8 (1), 9-16.

Motevalli, S., Perveen, A., \& Michael, M. T. A. (2020). Motivating students to learn: An overview of literature in Educational Psychology. International Journal of Academic Research in Progressive Education \& Development, 9 (3), 63-74.

Osman, W. A., \& Abu Bakar, A. L. (2009). Learning to write an academic paper among medical students of Universiti Malaysia Sabah. Proceedings of the $2^{\text {nd }}$ International Conference of Teaching and Learning (ICTL 2009) INTI University College, 1-21, Malaysia.

Raimes, A. (1991). Out of the woods: emerging traditions in the teaching of writing. TESOL Quarterly, 25(1),11-15.

Ismail, Sadiq. (2010). Exploring Students' Perceptions of ESL Writing. English Language Teaching. 4. Doi :10.5539/elt.v4n2p73.

Tan, B. H., Emerson, L., \& White, C. (2006). Reforming ESL writing instruction in tertiary education: The writing centre approach. The English Teacher. 25(1), 1-14.

Warschauer, M., \& Healey, D. (1998). Computers and Language Learning: An Overview. Language Teaching, 31, 57-71.

Yuen, C. K., \& Mussa, I. H. (2015). Academic Writing Difficulties of Iraqi Postgraduate Students in Malaysia,International Journal of Education and Researcg, 3(6), 25-34. 
INTERNATIONAL JOURNAL OF ACADEMIC RESEARCH IN BUSINESS AND SOCIAL SCIENCES

Vol. 11, No. 3, 2021, E-ISSN: 2222-6990 @ 2021 HRMARS

\section{Appendix 1: IQ-Write Program}

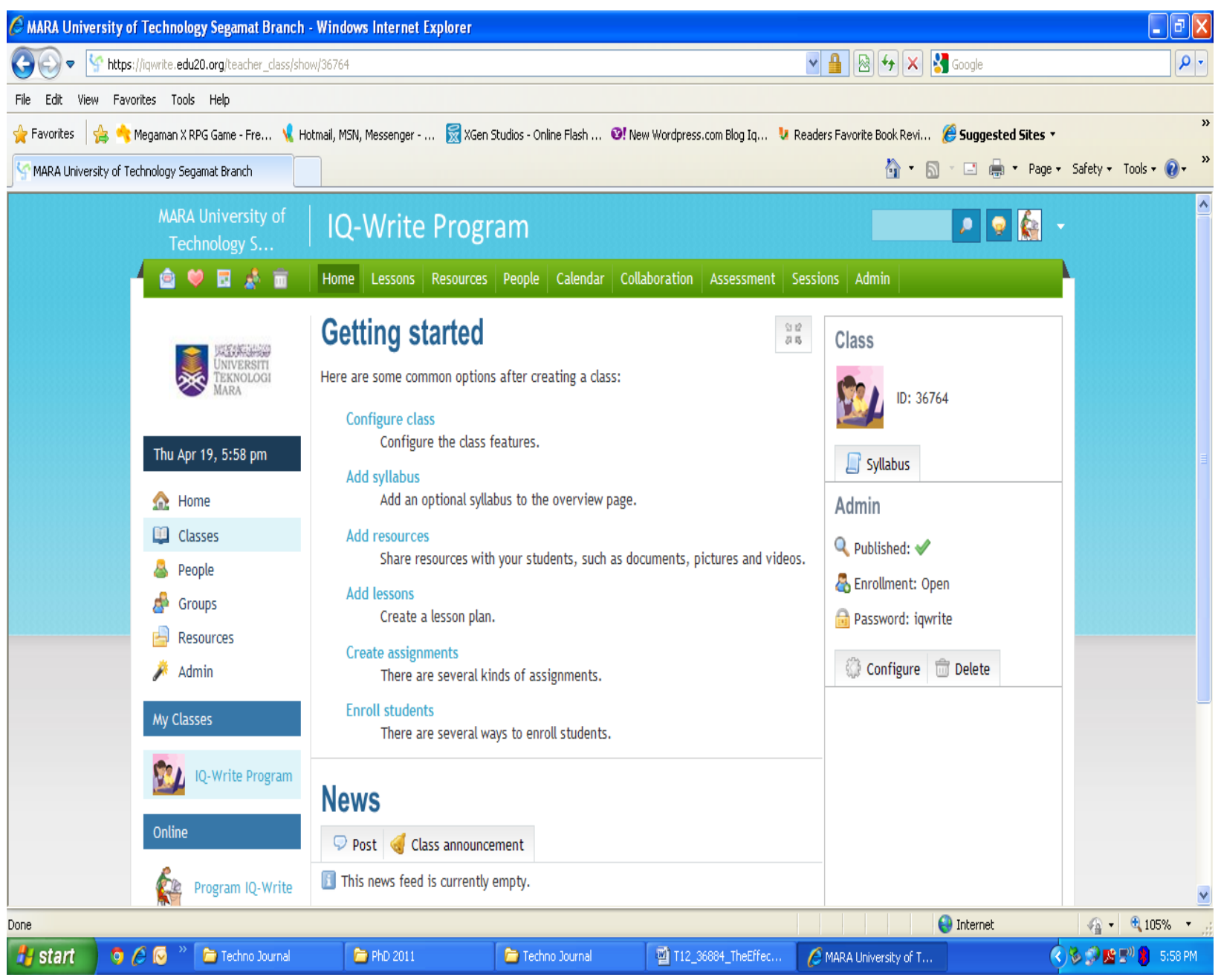


Appendix 2: Guide Sheet 1- ASK and Guide Sheet 2-FOCUS
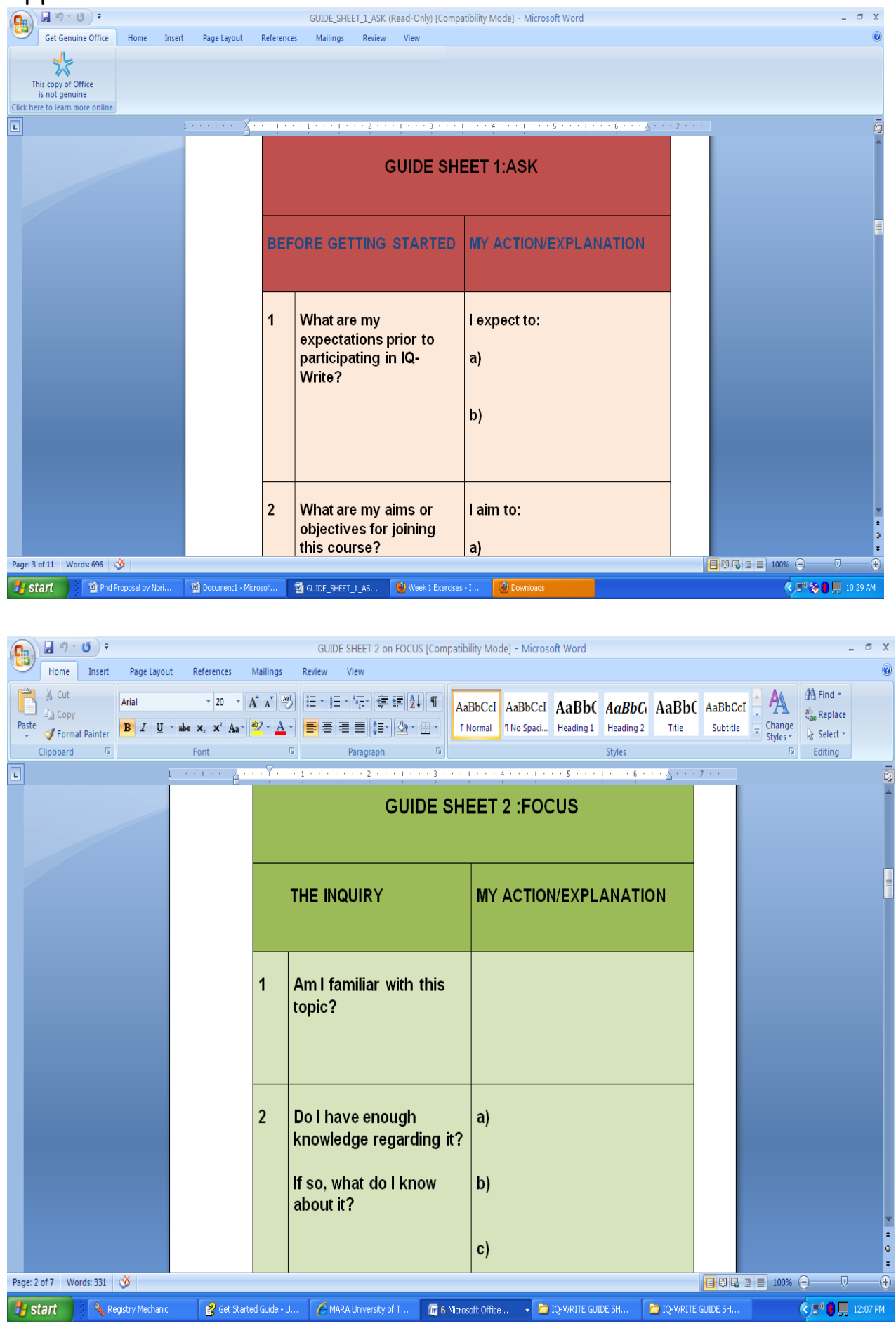